\title{
From Bentham to Guadet: 'Auditory Visibility' in Nineteenth-Century Theories on Government Offices
}

Jens van de Maele

\author{
HCM 7: 673-685
}

DOI: $10.18352 / \mathrm{hcm} .577$

\begin{abstract}
Architectural historiography is seldom concerned with the antithetical notions of 'noise' and 'silence'. In this case study, I tentatively explore the theme in the context of nineteenth-century administrative buildings. More particularly, I investigate the normative views of British and French authors concerning acoustic perception in one subtype of 'bureaucratic' architecture: the ministerial office building. Drawing examples from the work of, among others, 'panopticon' theorist Jeremy Bentham and the architect Julien Guadet, I point at the centrality of 'sound control' or 'sound management' in architectural discourses on office buildings. In the specific domain of ministerial offices, moreover, these discourses were rife with ideological views on the nature and the functioning of government itself.
\end{abstract}

Keywords: administration, architecture, Britain, civil service, France, government offices, ministerial offices, ministries, noise, office buildings, surveillance

\section{The Sounds of the Bureaucratic Machinery}

Large administrative organizations - let me call them, without pejorative intent, bureaucracies - always forge a distance between themselves and the public. The French jurist Jacques Chevallier has signalled that 
the prototypical modern bureaucratic institution makes ample use of strategies and techniques which generate 'exclusion and segregation', in order to guarantee the 'serenity' of the decision-making processes. Among these strategies, Chevallier lists the 'administrative secret', as well as the 'intentional delay' in the release of documents. Furthermore, personal interaction between the public and bureaucracies often passes through literal barriers: many organizations have used (and many still use) counters, which can be regarded as the material and symbolic locus (effectively an 'interface') where contact can be established in a controlled way. Indeed, when the inner workings of the administrative machinery remain hidden from the outside world, a bureaucracy often manages to evade investigation or external pressure. ${ }^{1}$ As a result, no bureaucracy can ever be a 'glass house', Chevallier claimed. ${ }^{2}$ To a large degree, a 'black box' seems to be a better-suited metaphor. ${ }^{3}$

With his references to architecture, which are at once metaphorical (a glass house) and concrete (the counter hall), Chevallier has drawn attention to the spatial and physical constitution of the bureaucracy. Interestingly, Chevallier's references point at two aspects of sensory perception: the visual and the auditive. In architectural historiography, most attention has been devoted to the former aspect, with its connotations of transparency and opaqueness. ${ }^{4}$ The element of acoustic perception, related to the everyday realities of conversation, sound and noise, has received less scrutiny, certainly with regard to architecture for bureaucracies. In this brief case study, I will tentatively explore the normative views of three nineteenth-century authors concerning acoustic perception in one particular subtype of bureaucratic architecture: the ministerial office building. Drawing examples from the United Kingdom and France, I want to point at the highly ambiguous centrality of 'sound control' or 'sound management' in architectural discourses on office buildings. In the specific domain of ministerial offices, moreover, these discourses were often rife with ideological views on the nature and the functioning of government itself.

\section{Towards 'Promptitude of Oral Intercourse'}

Let me start with Jeremy Bentham (I748-I832), probably the first author who has thoroughly reflected on the ways in which architecture 
can (or rather should) shape political and administrative practices. While Bentham and his 'panopticon' have become household references in different areas of cultural studies through the work of Michel Foucault, ${ }^{5}$ surprisingly few scholars outside the field of 'Bentham studies' have noticed that the English jurist and philosopher was not only a self-proclaimed prison reformer, but also (and, in his own eyes, perhaps more crucially) an aspiring reformer of government. For most of his life, Bentham sought to implement radical modernizations in politics, the judiciary and the public administration. Crucial aspects of his plans indeed revolved around the concept of the panopticon, although his thinking on this topic evolved throughout the years, as he constantly developed new areas of application for the panoptic scheme: schools, military barracks, hospitals and, finally, government. For this reason, Bentham scholar Anne Brunon-Ernst has coined the plural notion of 'panopticons': there is no such thing as one definitive panoptic system that can be attributed to the thinker. ${ }^{6}$ While Foucault has famously singled out the 'prison panopticon' as the essence of both Bentham's world view and all modern, totalitarian strategies of oppression, many aspects in Bentham's political writings can in fact be interpreted as strategies for the achievement of far more benign principles, such as the elimination of corruption in government, or the notion that politicians ought to be held accountable for their actions at all times. ${ }^{7}$ Architecture played a crucial role in these proposals, as Bentham asserted himself in Constitutional Code (I 830), his magnum opus on governmental reform: '[On] architecture, good Government has more dependence than men have hitherto seemed to be aware of." 8

The nature of Bentham's intentions should be understood in the light of utilitarianism, the ethical doctrine which holds that the sole purpose of moral and political acts should be the maximization of happiness among the largest possible number of people. Yet, since everyone tries (in Bentham's view) to maximize his or her own personal happiness (sometimes, if not often, at the cost of other people's happiness), Bentham complemented his ethical directives with an almost methodological attitude of distrust towards all human beings. His distrust towards politicians and civil servants was particularly well-developed, since these men often held positions which involved the handling of public monies. To eradicate the possibility of abuses, Bentham wanted to submit all public functions to a so-called 'confidence-minimization 
principle', which was to be complemented with a 'control-maximization principle'. Together, these principles held that every member of the public should be given full insight in all political and administrative actions at any time, with the aim of deterring misbehaviour. ${ }^{9}$

Given his strong emphasis on the creation of a well-informed public opinion, Bentham believed that the practice of government was to be driven by an urge towards transparency, or, as he called it, 'publicity'. Conversely, the philosopher was a strong opponent of the secrecy that usually was (and still is) associated with bureaucracies. ${ }^{\text {Io }}$ As such, he emphasized that the architecture of government offices had to be permeated with the postulated ideal of 'publicity'. In Constitutional Code, he specified that the ministerial offices of any given country had to be centralized in a newly built, well-ventilated and well-lighted building with a circular, semi-circular or oval shape. ${ }^{11}$ The Prime Minister would be given an office at the centre, since he was the most important figure in government and spent much of his time delegating to ministerial colleagues. ${ }^{12}$ In combination with the building's compact circularity, the central location would shorten the distance between the Prime Minister's office and all other office rooms, as well as 'the time consumed in passing to and fro' ${ }^{13}$ Centralizing all administrative services in one building would, moreover, eliminate the possibility that messengers got 'robbed' when carrying paperwork between offices. ${ }^{14}$ The personal office of each minister (of which there were to be thirteen in total, the Prime Minister included) would consist of a private section (where one could retreat for resting) and a 'public' section. The latter section of every office was to be surrounded by a number of waiting rooms with 'counters', from where the public could interrogate the ministers. Most of these waiting rooms were to be organized in such a way that the interrogations could be followed by anyone attending, 'as in the boxes of a theatre'. Only in exceptional cases, when informants had to be protected against eavesdroppers, Bentham deemed the use of private 'waiting boxes' legitimate. ${ }^{15}$

Considering any waste of time as an intolerable squandering of both human effort and government funds, Bentham further projected the installation of 'conversation tubes', in order to maximize the 'promptitude of oral intercourse' between offices. These tubes, which the philosopher had originally proposed for his panoptic prison, would allow mutual communication between the ministers, who would each have 
about twelve tubes at their disposal. ${ }^{16}$ In contrast with some of his earlier writings on panopticons, Constitutional Code did not suggest that all of the building's occupants had to be subjected to the permanent, monocentric, visual gaze of a supervisor. Hence, the centrally located Prime Minister should not be conceptualized as some kind of supreme overseer who remained unseen himself. Bentham's plans for government offices rather suggested that all ministers were to keep each other under permanent scrutiny by means of 'auditory visibility' (and here, I use an oxymoron that has been coined, in a different context, by art historian Anna Vemer Andrzejewski). ${ }^{17}$ As such, two elements became strategies for the achievement of 'publicity': on the one hand the auditory 'gaze' among the ministers themselves; on the other hand the visual as well as auditory gaze of the public in the waiting rooms. There were indeed many potential gazes in Bentham's government offices, but in principle, anyone being gazed at could return the gaze: contrary to the panoptic prison, the surveillance system for the government offices was pluricentric. $^{\text {I8 }}$

Lastly, Constitutional Code projected the creation of a 'Ministry of Legislation', which would be permanently open to the public. In this way, the civil servants, who were to be monitored at all times, could show how the preparation of laws and the implementation of orders worked in practice, while all official documents had to be kept nearby, in publicly accessible archival rooms. The Ministry of Legislation was thus supposed to serve a pedagogical purpose as a kind of 'school' of government. ${ }^{19}$ During their visit, citizens would have the right, or even the duty, to address their officials critically, Bentham emphasized: 'The military functionary is paid for being shot at, the civil functionary is paid for being spoken and written at. ${ }^{20}$ In sum, silence was clearly not something Bentham was striving after. Instead, the ministerial office had to be buzzing with conversation, all for the sake of utilitarian logic and governmental efficiency.

\section{'Shut Up' in Private Rooms?}

No earlier than the mid-I850s, the architectural principles propagated in Constitutional Code would find some resonance in Bentham's homeland, even though is its unclear if this resonance resulted from causal 
influence. Architectural historian Pedro Guedes has recently brought an obscure I855 pamphlet into the spotlight, in which the unsatisfactory administrative procedures and the outdated offices of the British Ministry of War were criticized. Indignant about the debacles of the British army in the ongoing Crimean War, the anonymous pamphleteer (who was most probably a civil servant himself) proposed a drastic reform of the War administration. The construction of a new ministerial office building, whose architecture was to be based on the iron and glass structure of the Crystal Palace (I85I), emerged as an essential part of his reform proposal, Guedes explains:

[The proposed] three-story 'War Administration Building' brought everything together into a single compact space - a hive of activity where close to IOoo clerks would work efficiently in concert in one room measuring I IO $\mathrm{x} 58,5 \mathrm{~m}$. In it every stage in processing orders could be carried out in proper sequence in methodical work-flow, tuned to the most efficient layout ... Clerks sitting at desks arranged in rows to suit tasks would process paperwork and make copies as required, all under constant supervision. Furniture would be kept low to facilitate visibility, and all partitioning would be non-structural and removable, so that it could be rearranged in response to changing requirements. ${ }^{21}$

While Constitutional Code had not offered recommendations concerning iron and glass as building materials or concerning the use of flexible partitions, its author would surely have approved of the confidenceminimizing logic proposed by the 1855 text. Like Bentham, the anonymous pamphleteer believed that a regime of surveillance, both visual and auditory, had to cover all administrative ranks, although he did not go as far as to include the minister in his scheme. The necessity to have all governmental employees continuously monitored, was substantiated in the pamphlet as follows:

Thorough supervision is as necessary with clerks as with other men, and can never be obtained when they are boxed and shut up in different rooms [i.e. separate offices, $j v d m$ ]. No doubt, under a system which permits a chief officer of a department to lounge all of his mornings away in his club, the chief clerk having become the real head of it, considers himself entitled to a private sitting room and other luxuries, but that is not the way to get work done. In [our] plan, there are no such snug places provided. But each 
chief clerk of a department [of the Ministry of War] has nevertheless a separate space enclosed on three sides for himself and his principal clerks, and he may be allowed to carpet it and enclose the fourth side by drawing a curtain, if his dignity requires it, although we by no means recommend it. ${ }^{22}$

Despite the similarities with Bentham's proposals, the I855 text evoked a rather different attitude towards conversation. Having government employees firmly engaged in discussion (either with one another or with members of the public) no longer appeared as a (positive) strategy for creating 'publicity', since the work stoppage of any single employee would have fatally interrupted the 'methodical work-flow'. Together with the advice that desks should be arranged in rows (much like in a typical school environment), ${ }^{23}$ the ideal typical image emerged of a workplace in which most employees were silenced, and in which the supervising 'chief clerks' and 'chief officers' were given the monopoly on verbal communication. Yet, in a certain sense, even these supervisors were subjected to a sound-minimizing regime: after all, whenever the 'chief clerks' wanted to retreat in order to discuss confidential matters, their curtained 'private spaces' provided little in terms of acoustic privacy.

While the immediate influence of the I855 pamphlet seems to have been non-existent, the importance of having civil servants monitored at all times would be reiterated one year later by the high-ranking English civil servant Charles Trevelyan (who had earlier co-authored an important official report on the reform of the British public administration). In an I856 memorandum, Trevelyan (I807-I886) made a plea for the construction of new ministerial office buildings, equipped with spacious rooms 'for the more mechanical work', where 'a number of clerks [would work in concert] under proper superintendence'. For the 'intellectual work', Trevelyan suggested the provision of 'separate rooms ... so that a person who works with his head may not be interrupted'. ${ }^{24}$ Here, it becomes clear that the concepts of 'visibility' and 'surveillance' were increasingly being narrowed down, with the aim of having them applied to lower-ranked employees solely. This was a further deviation from Bentham's I830 proposals, which provided in 'publicity' for all those holding public positions, indiscriminate of rank and function. At the same time, however, Trevelyan was one of the first who implicitly acknowledged that noise was a daily reality (as well as a nuisance) in the ministerial offices. Apparently, the low-ranking clerks 
who worked 'in concert' were not by definition silent, or maybe the silence was continuously interrupted by the commands emanating from the supervisors. (Here, it should be taken into account that the noise could not yet have been produced by machinery such as typewriters, telephones or dictaphones: typewriters, for instance, made their breakthrough no earlier than the I880s.25) From this point of view, granting privacy to 'intellectual' workers was not so much a matter of prestige or a privilege for 'snug' high-ranking personnel (as the I 855 pamphleteer had seen it), but rather a functional necessity: without a silent, enclosed room, these brain workers could not get much work done. ${ }^{26}$

\section{'Neither Eyes nor Ears'}

For my last example, I turn to the French 'proto-modernist' architect Julien Guadet (I834-I908), ${ }^{27}$ who published a reputed handbook, Élements et théorie de l'Architecture, towards the end of the 'long' nineteenth century. According to the British architectural historian Peter Collins, Guadet's multi-volume handbook (which first appeared between I90I and I904) can be considered as 'the first really thorough study' of 'building types applicable to the new age'. ${ }^{28}$ Due to the accelerated growth of both governmental and commercial bureaucracies in many countries during the fin de siècle, offices unmistakably came to belong to this category of buildings. As such, Guadet was also one of the first architectural theorists who explicitly discussed the office as a typology in itself. ${ }^{29}$ Illustrating his text with buildings like the Parisian Hôtel du Ministère des Affaires Etrangères (built I844-I856), ${ }^{30}$ he summarized his views on the ideal internal disposition of any given office complex as follows:

For the [lower-ranking] employees, well-lighted and sufficiently comfortable offices suffice, which must be large enough to accommodate multiple workers. One room for every employee would be too expensive a luxury; moreover, employees often have to work together ... For the sake of surveillance, economy, scarcity of space, etc, many [institutions] have pleaded for a concentration in a single office room of all employees belonging to a single service ... Concerning the chefs and sous-chefs, who often need to treat matters with discretion: they should have personal rooms. ${ }^{31}$ 
Anyway, I cannot wind up without signalling the necessity of discretion. Sometimes, directors have to receive persons whose presence should not be revealed to anyone, and in such cases, it is imperative that the walls have neither eyes nor ears..$^{32}$

In these sentences, Guadet intuitively listed a number of elements which would become programmatic in the domain of office design during the first half of the twentieth century (and even beyond): the pre-eminence of 'economy', the generation of fluid communications between different services in an organization, the stress on ample lighting, and the creation of hierarchized spatial arrangements, with a grouping of the low-ranking personnel in large 'open' rooms. The necessity to exert 'sound control' was also brought into the limelight, even though the difference with Trevelyan's writings is striking. Guadet's concern did not primarily lie in protecting the 'intellectual workers' from the noises made by the lower-ranking employees. Instead, the conversations of the upper-ranking had to be protected against proliferation among the lower-ranking and, as one may assume, the public. Like in the world of business, the political and administrative leaders of the ministries could not do without a degree of secrecy.

In conclusion, it is clear that the high ideal of universal visual and acoustic surveillance set by Bentham was not endorsed by subsequent authors. The I 855 British pamphleteer eliminated the minister from the regime of surveillance, Trevelyan eliminated the 'intellectual' workers, and Guadet defended outright the idea that top-ranking employees were entitled to privacy whenever they deemed fit. In the normative discourses concerning low-ranking clerks, however, the legacy of Bentham's panoptic scheme, with its confidence-minimizing regime, remained intact. Only after the World War I, when architectural and administrative experts became influenced by the principles of Scientific Management (F.W. Taylor, I9I I), new attempts would be made to bring top-ranking employees firmly into the realm of surveillance: by using soundproofed glazed partition walls, members of the higher management could be granted 'acoustic' privacy while staying visible for colleagues. ${ }^{33}$ However, one element would remain constant (and this far into the twentieth century): the relative lack of interest among managerial and architectural theorists regarding the noise to which low-ranking employees were often exposed. 


\section{Notes}

I Jacques Chevallier, Science administrative (Paris, 2007) 34I-43. All translations throughout the article by the author.

2 Ibid., 446-47.

3 On the conceptualization of administrative workspaces as 'black boxes', see Peter Becker, 'Sprachvollzug: Kommunikation und Verwaltung', in Becker (ed.), Sprachvollzug im Amt: Kommunikation und Verwaltung im Europa des I9. und 20. Jahrhunderts (Bielefeld, 20I I) 9-43, at 32-3; Hartmut Böhme, 'Das Büro als Welt - die Welt im Büro', in Herbert Lachmayer and Eleonora Louis (eds), Work \& Culture: Büro, Inszenierung von Arbeit (Klagenfurt, I998) 95-I30, at 98.

4 On transparency in office buildings, see Cordula Seger, 'Das Büro als Gesellschaftsspiegel', Kunst + Architektur in der Schweiz, 58:I (2007) 6-I2, at 8. On architectural transparency in general, see for instance Sascha Roesler, 'Von Glashaus zum gläsernen Menschen: "Transparenz" als Ideologie der Moderne', Kunst + Architektur in der Schweiz, 58: I (2007) 30-8; Deborah Ascher Barnstone, The Transparent State: Architecture and Politics in Postwar Germany (London and New York, 2005); Annette Fierro, The Glass State: The Technology of the Spectacle, Paris I98I-I998 (Cambridge MA and London, 2003); Hilde Heynen, "'In elk schuifraam schuilt de belofte van een toekomststaat": Over architectuur, transparantie en utopie', in Madelon de Keizer et al. (eds), Utopie: Utopisch denken, doen en bouwen in de twintigste eeuw (Zutphen, 2002) I07-25; Adrian Forty, Words and Buildings: A Vocabulary of Modern Architecture (London, 2000) 286-288; Mark Rakatansky, 'Spatial Narratives', in John Whiteman, Jeffrey Kipnis and Richard Burdett (eds), Strategies in Architectural Thinking (Cambridge MA and London, I992) I98-22 I, at 204.

5 For a typical synthesis of Bentham's ideas via Foucault, see for instance Simon Gunn, History and Cultural Theory (Harlow, 2006) 94-96.

6 Anne Brunon-Ernst, 'Deconstructing Panopticism into the Plural Panopticons', in Anne Brunon-Ernst (ed.), Beyond Foucault: New Perspectives on Bentham's Panopticon (Farnham and Burlington, 2012) I 7-4I.

7 Cyprian Blamires, The French Revolution and the Creation of Benthamism (Basingstoke and New York, 2008), 3, 6, 22-3 and 30.

8 Jeremy Bentham, Constitutional Code for the Use of all Nations and all Governments Professing Liberal opinions (vol. I) (London, I830) 60. See 
also: Guillaume Tusseau, 'From the Penitentiary to the Political Panoptic Paradigm', in Brunon-Ernst (ed.), Beyond Foucault, I I5-I40, at I27. Constitutional Code was originally written after a request by the Portuguese Cortes in I822, and was intended as an all-encompassing lawbook for the political and administrative functioning of a democratic state. When its implementation in Portugal backfired, Bentham tried to offer his services to Greece, Tripoli, Spain, Bavaria and South-American states, all to no avail.

9 Emmanuelle de Champs, La déontologie politique, ou la pensée constitutionelle de Jeremy Bentham (Geneva and Paris, 2008) 350-I.

Io Dilip Parameshwar Gaonkar and Robert J. McCarthy Jr., 'Panopticism and Publicity: Bentham's Quest for Transparency', Public Culture 6:3 (I994), $547-75$, at 558 .

I I Bentham, Constitutional Code, 57I-98. See also: Brunon-Ernst, 'Deconstructing Panopticism', 29-32.

I2 Bentham's ideas were formulated to be applicable in any country. This did not prevent the philosopher from taking a number of British political customs, including the concept of a 'Prime Minister', as a model.

I3 For Betham's view on the principle of 'compactness' in architecture, see L.J. Hume, Bentham and Bureaucracy (Cambridge etc., I98I) I42.

I4 Bentham, Constitutional Code, 579. Bentham prescribed one exception to his centralizing ideal: 'As to the office of the Justice Minister, this should rather be remote from, than contiguous to, the above-mentioned cluster of offices. Between the Administrative Department and the Judiciary, the less the unseen and unheard communication, the better.' Ibid., 598.

I 5 Ibid., 58 I-2. See also Tusseau, 'From the Penitentiary', I27; Frederick Rosen, Jeremy Bentham and Representative Democracy: A Study of the Constitutional Code (Oxford, I983), I I4-5.

I6 Bentham, Constitutional Code, 579. See also Hume, Bentham and Bureaucracy, 234.

I7 Anna Vemer Andrzejewski, Building Power: Architecture and Surveillance in Victorian America (Knoxville, 2008) 5.

I 8 Bentham did not use the word 'panoptic' in Constitutional Code. However, the architectural concept for the ministerial offices can by all means be considered as a variation on Bentham's previous panoptic schemes. See: Brunon-Ernst, 'Deconstructing Panopticism', 24.

I9 De Champs, La déontologie publique, 354; Tusseau, 'From the Penitentiary', I 28.

20 Bentham, Constitutional Code, 40. See also: Rosen, Jeremy Bentham, I 2. 
2 I Pedro Guedes, 'Free Plan for the I850s: Forgotten Imagined Architectures from Mid-Century', Architectural History, 57 (20I4) 239-75, at 247. The pamphlet itself was entitled A Remedy for the Evils that have Caused the Destruction of a Large Portion of the British Army before Sevastopol.

22 Cited by Guedes, 'Free Plan', 248. Even though his article mentions the panoptic prison, Guedes does not refer to Bentham's texts on government offices.

23 The similarity between a row-like office desk arrangement (which was a common feature of many offices until the introduction of the 'landscape office' in the I960s) and a typical classroom layout has been noted in a popularizing history book: Élisabeth Pélegrin-Genel, The Office (Paris and New York, I996) 38.

24 Cited by Michael Harry Port, Imperial London: Civil Government Building in London, I850-19I5 (New Haven and London, I995) 33.

25 On typewriters and other kinds of office equipment, see for instance Delphine Gardey, Écrire, calculer, classer: Comment une révolution de papier a transformé les sociétés contemporaines (Paris, 2008) 84-8; Francis Duffy, 'Office buildings and organisational change', in Anthony D. King (ed.), Buildings and Society: Essays on the Social Development of the Built Environment (London, I980) 254-80, at 266.

26 Like the I 855 pamphlet, Trevelyan's I 856 memorandum appears to have had no immediate influence on government architecture in Britain. See Port, Imperial London, 35-6.

27 Jacques Lucan, Composition, Non-Composition: Architecture and Theory in the Nineteenth and Twentieth Centuries (Lausanne, 20I2) I7I.

28 Peter Collins, Changing Ideals in Modern Architecture, I750-I950 (London, I 965$)$ 223. On Guadet, see also Lucan, Composition, 6, I 9 and I 58-7 I; Forty, Words and Buildings, 90-2; Hanno-Walter Kruft, A History of Architectural theory: From Vitruvius to the Present (New York, I994) 288-9.

29 Another early case is a chapter in the Handbuch der Architektur (I887) by the Prussian Royal Land-Bauinspector Albert Kortüm, which provided a short, descriptive survey of governmental offices that had been constructed since the I850s in Paris, Berlin, Vienna, Washington, London and Calcutta. See Albert Kortüm, 'Gebäude für Ministerien, Botschaften und Gesandtschaften', in Josef Durm et al. (eds), Handbuch der Architektur: vierter Theil (entwerfen, anlage und einrichtung der Gebäude), 7; Halb-Band (Gebäude für Verwaltung, Rechtspflege und Gesetzgebung; Militärbauten) (Darmstadt, I 887) 84-Ioo. 
30 Julien Guadet, Éléments et théorie de l'architecture: Cours professé à l'École Nationale et Spéciale des Beaux-Arts (tome II) (Paris, s.d. [reprint of the first I90I edition, ca I90I-I9I0]) 386-87.

3I Ibid., 385 .

32 Ibid., 39I.

33 On glazed partitions, see for instance: Vemer Andrzejewski, Building Power, 70-I; Peter Cachola Schmal and Wolfgang Voigt, 'Immer eine große Linie: Das Verwaltungsgebäude der I.G. Farbenindustrie in Frankfurt am Main und andere Verwaltungsbauten', Wolfgang Pehnt and Matthias Schirren (eds), Hans Poelzig: Architekt, Lehrer, Künstler (Munich, 2007) I I 2-25, at I I 7 and I23; Iñaki Ábalos and Juan Herreros, Tower and Office: From Modernist Theory to Contemporary Practice (Cambridge MA and London, 2003) I9I; Carol Willis, Form Follows Finance: Skyscrapers and Skylines in New York and Chicago (New York, I995) 27.

\section{About the Author}

Jens van de Maele studied history at the universities of Leuven and Vancouver. He is currently working on a PhD thesis dealing with political and architectural discourses on ministerial office buildings in Belgium during the interwar period, at University of Ghent and the University of Antwerp. E-mail: jens.vandemaele@gmail.com 